\title{
İmkân Mefhûmu ve İslam Filozofları ile Mütekellimler Arasında Delil Olarak Kullanımı
}

Hakan Kutlu*

\section{Öz}

Evrenin bir parçası olan insan içinde bulunduğu âlemin ve kendisinin varlığı hakkında sorgulamalarda bulunarak müşahede ettiği varlığı akli açıdan anlaşılabilir kılmaya çalışmıştır. Bizler de çalışmamızda bu çabanın madde itibariyle bir yönünü teşkil eden imkân mefhûmuna ve delil olarak kullanımına 1ş1k tutmaya çalıştık. Bu mefhûmun ortak bir paydada tarih boyunca kullanımına işaret ederken, İslam dünyasındaki kullanımı noktasında İslam filozofları ile mütekellimler arasındaki farkı ortaya koymaya gayret gösterdik.

Anahtar Kelimeler: İmkân, istihâle, vücûb, İslam filozofları, mütekellimler.

* $\quad$ Arş. Gör., Fatih Sultan Mehmet Vakıf Üniversitesi İslami İlimler Fakültesi Temel İslâm Bilimleri Anabilim Dalı, İstanbul/Türkiye, hkutlu@ffsm.edu.tr, orcid.org/0000-0002-7145-9092 


\title{
The Notion of Possibility (Imkan) and Its Usage as an Evidence Between Islamic Philosophers and Mutakallimun
}

\begin{abstract}
The human being, as a part of the universe, has been questioned about his being and the realm he is in; and tried to make it understandable from a rational point of view. In this paper, I have tried to shed light on the concept of imkan (notion of possibility) that constitutes an aspect of this effort and its usage as an evidence. While i have pointed out this notion's use throughout history in a common ground, $i$ have also endeavored to reveal the difference between Islamic philosophers' and mutakallimun's use that notion in the Islamic world.
\end{abstract}

Keywords: Imkân (notion of possibility), istihâle (transform), vujub (obligation), Islamic philosophers, mutakallimun. 


\section{Giriş}

İnsanlığın tarihi seyri incelendiğinde kendisinin de bir parçası olduğu evrenin nasıl var olduğu birçok insan tarafından araştırılmıştır. Farklı kişiler ve zümrelerden birbirinden çok ayrı sebepler ortaya koyanlar olduğu gibi dikkatli bir şekilde okunduğu vakit Yunan filozoflarından tutalım da İslam filozofları, mütekellimler hatta son dönem batılı düşünürlere kadar yapılan izahlarda evrenin var edicisi olan zatın bu evrenden varlık açısından fark11 olduğu fikrinin ortak bir zemin oluşturduğu da görülür. Oluşan bu ortak çerçevenin adının da genel itibari ile "evrenin imkânı" mefhûmu olduğunu söyleyebiliriz.

Çok farklı kesimler tarafından ulaşılan bu netice hem muhatap ile ortak bir dil yakalama hem de sağlamlık açısından kullanılabilirliği içermesi gibi hususiyetler ile çok yüksek bir delil değeri taşımaktadır. Elbette herkes düşündüğü ve inandığg şeyleri öncelikle kendi açısından kabul edilebilir kılma ve daha sonra da muhataplarına karşı da bu durumunu koruma, belki de onları da kendi ile aynı noktaya çekme gibi amaçları taşıyabilirken bunu en sağlam delilleri kullanarak yapmaya çalışır.

Delilin sağlamlığı ise beş duyu organlarının ilgi alanına girmesi, akli zorunluluklardan olması veya onlara dayanması ve sadık habercinin bildirimlerinden olmas1 ${ }^{1}$ gibi ölçüler esas alınarak tayin edilmiştir. Argümantasyon noktasında kullanılan imkân mefhûmunun da birçok İslam filozofu ve mütekellim tarafından aklın zaruri olarak kavradığı mefhûmlardan olduğu ortaya konmuştur. ${ }^{2}$ Zaruri oluşu sebebiyle bu kavram kullanılarak yaratıcının, varlığı açısından âlemden farklı bir noktada yani vâcibu'l-vücûd olduğu ispat edilmeye çalışılmıştır. Ancak bedihi olan bu mefhûmun ele alınması bakımından da bazı farklılıklar olduğu göze çarpmaktadır. Bizler bu çalışmamızda özellikle İslam filozofları ile mütekellimler arasında bu mefhûma bakıştaki farkı belirlemeye çalışacağız. Aynı zamanda her iki tarafın kullanımına dair örnekler vererek okuyucunun da meseleyi bizzat iddia sahiplerinin kendi metinlerine bakarak değerlendirebilmesine vesile olmaya çalışacă̆ı.

1 Nureddin es Sâbûnî, el Bidâye fî usûli'd-dîn, çev. Prof. Dr. Bekir Topaloğlu, İstanbul, MÜİF Yayınlar1, 2014, s. 45.

2 Abdüllatîf Mahmûd Said Fûde, "el Edilletü'l-akliyye li vucûdillah beyne'l-felâsife ve'l-mütekellimîn”, (Yayımlanmamış Doktora Tezi), Amman Uluslararası İslam Üniversitesi Yüksek İhtisas Fakültesi Usûlü'd- Dîn Kısmı, Amman, 2014, s.220. 


\section{1. İmkân Mefhûmu İle Alakalı Meseleler}

\section{1. İmtina' Vücûb ve İmkân Kavramlarının Anlamı}

Çalışmamızın mevzusunu oluşturan imkân delilini ele alabilmek adına öncelikle imkân mefhûmuna ve bu mefhûmun anlaşılması için beraberinde vücûb ve İstihâle' kavramlarına da ana hatlarıyla temas etmemiz faydalı olacaktır.

İstihâle: Bir şeyin, zatından dolayı varlığının tasavvur edilememesi,

Vücûb: Bir şeyin, zatından dolayı yokluğunun tasavvur edilememesi,

İmkân: Bir şeyin, zatından dolayı varlığı ya da yokluğunun tasavvur edilebilmesi demektir. ${ }^{3}$

$\mathrm{Bu}$ üç kavram ile alakalı yapılan tariflerin genel itibari ile bu minvalde olduğunu rahatlıkla söyleyebiliriz. Zira kavramlar Cürcânî'nin de ifade ettiği gibi tabiatı ile tariflerin "devir" içermesine sebep olmaktadır:

" Kim de bu kavramları ve onlardan türetilen lafızları tarif etmeye çalışırsa, ele aldığ 1 kavramı kalan ikisinden birini ya ispat ya da nefyederek tanımlamak zorunda kalır. En nihayetinde şu ifadelerin dışına çıkması mümkün değildir: Vâcib yokluğu imkânsız olan veya mümkün olmayandır, mümteni' yokluğu zorunlu olan veya varlığı mümkün olmayan$\underline{\text { dır}}$, mümkün varlığı da yokluğu da zorunlu yahut imkânsız olmayandır. Görüldüğü üzere varlığın zorunlu formu tanımlanırken, yokluğa nispet edilerek ve mümteni' kavramına müracaat edilmesi, mümteni' kavramı için zorunluluğun yokluğa bağlanması veya varlık yönündeki imkânın nefyedilmesi, mümkün kavramında ise hem varlık hem yokluk açısından zorunluluk ve imkânsızlığın devre dışı bırakılması gerekmiştir. Bu da apaçık bir devirdir". ${ }^{4}$

Mezkûr kavramların tarifinde güçlük çekilmesinin nedeni ise insanın fitraten kavrayabileceği kadar bedihi ${ }^{5}$ olmaları ve aslında tarif edilmesinin bile gerekli olmayışıdır. Bu kavramların zaruri oluşuna İbn-i Kemmûne de şu ifadeler ile dikkat çekmektedir:

3 Seyyid eş Şerîf Cürcânî, Mu'cemu't- Ta'rifât, Dâru'l- Fazîle, s. 33, Cürcânî aynı zamanda imkân'ın çeşitlerini imkân-1 zâtî, imkân-1 isti'dâdî, imkân-1 âmm ve imkân-1 has olarak sıralamaktadır. Mütekellimlerin mutlak olarak ele aldıkları vakit imkân mefhûmundan kastettikleri “Mümkün'ün her iki şıkkında da zorunluluğun bulunmaması" manasına gelen "imkân-1 has" tır. Ayrıntılı bilgi için bkz. a.g.e, s. 33.

4 Fûde, a.g.e, s. 102.

5 M. Naci Bolay, "Bedihi”, $D \dot{I} A$, c. 5, 1992, s. 322-323. 
"Vücûb, imkân, istihâle ve bu kavramlarlardan elde edilen manalar bedihi olarak idrak edilir. Her insan bilfiil zorunlu olarak canlı olduğunu, yazıcı olmasının imkânını ve taş olmasının imkânsızlığını bilir”. 6

Verilen örnekteki ifadeleri, mütekellimlerin kastettiği mana ile aradaki fark1 göz önünde bulundurmaksızın değerlendirecek olursak kavramların zaruri oluşunu tembih ${ }^{7}$ etmesi açısından rolü son derece önemlidir.

Kavramların aslında bu denli zaruri olmasının nedeni de insan nezdinde en bedihi ve ilk fark edilecek şey olan "vücûd" mefhûmuna dayalı olarak verilen hükümlerden ibaret olmalarıdır. Eş-Şehhu'r-Reîs: "Lâ şekke enne hünâke vücûden" yani "asıl ititbari ile varlık diye bir şeyin olduğu şüphe barındırmayan bir durumdur" diye tercüme edebileceğimiz ifadesi ile âlemin meydana geliş sebebini anlamlandırma çabasının merkezine vücûd mefhûmunu yerleştirmiştir. ${ }^{8}$ Dolayısıyla bir mefhum olarak varlık ele alındığı vakit akıl, onun var olmasının zorunlu olduğuna ya da olmadığına hükmedebilecektir ki bu iki ihtimal birbirinin çelişiği durumundadır; mümteni' ise doğası itibari tahakkuk etmeyişi gerektirdiğinden zaten vücûd içerisinde ele alınamamaktadır. O halde aklın, varlığının zorunluluğuna hükmettiği vâcib, olmadığına hükmettiği ise mümkün olmaktadir.

\section{2. İmkân Mefhûmu ve İmkân Delilinin Oluşumu}

İmkân mefhûmu yukarıda da tarif olunduğu üzere bir şeyin zatı itibari ile varlığı ya da yokluğu gerektirmemesi demektir. Zatı itibari ile varlık ya da yokluğu gerektirmemesi kaydından, iki şıktan birinin varlığı söz konusu olduğunda

6 Fûde, a.g.e, s. 102.

7 İmam Gazzâlî idrak açısından zaruri olan şeylerin izahı için girilen uğraşları "tembih" olarak ifade etmiştir. Çünkü zaruri bir bilgi izaha ihtiyaç göstermez. (Bu, aradığı bir eşyayı elinde tuttuğu halde fark etmeyen ve uyarılması ile beraber onu elinde tuttuğunu fark eden kimsenin durumu gibidir.) Ayrıntılı bilgi için bkz. Huccetü'l-İslam Muhammed b Muhammed el Gazzâlî, el İktisâd fi'l-i'tikâd, Dâru'l-Minhâc, 1437, s. 56.

8 Veysel Kaya, “Felsefî̀ Kelam Çerçevesinde İbn-i Sînâ'nın Kelam’a Etkileri”, (Yayımlanmamış Doktora Tezi), Uludağ Üniversitesi Sosyal Bilimler Enstitüsü Temel İslam Bilimleri Anabilim Dalı Kelam Bilim Dalı, Bursa, 2013, s. 122. Aynı zamanda İmam Gazzâlî’de "Lâ şekke fî asli'l-vücûd” ifadesi ile varlık kavramının şüpheye mahal vermeyeceğini aynı manada bir ibare ile ifade etmiştir. Bkz. Gazzâlî, a.g.e, s. 67, Fahreddîn er- Râzî ise varlığı “evzahu'l-vâzıhât” olarak ifade ederken tarif edilmesinin mümkün olmadığını, tarif edilenin tariften daha açık olduğu durumlarda tarifin gayesine hizmet edemeyeceğini söylemektedir ki devamında varlıktan daha açık bir şey olmadığına da işaret etmektedir. Bkz. Nihâyetü'l-Ukûl fî Dirâyeti'l-Usûl, Saîd Abdüllatîf Mahmûd el Fûde, Beyrut, Dâru'z- Zehâir, 2015, s. 123-4. 
bu noktada kendisinden başka bir zata dayanmasının gerekli olduğu anlaşılmaktadır ki bu durumda imkân tam anlamıyla başkasına ihtiyaç duyma durumunu karşılar. İmkân mefhûmunu ifade etmeye çalıştığımız biçimde ele aldığımız zaman; "mümkün başkasına muhtaç olandır" şeklinde kurulan bir cümlede özne ile yüklem arasındaki bağ zihinde zaruri olarak idrak edilir. ${ }^{9}$ Aynı zamanda mümkünün kendisinden başkasına muhtaç oluşu sadece varlığın başlangıcı veyahut sonlanması ihtimallerinden yalnızca birine münhasır da değildir. Varlığı zatının gereği olmadığından nasıl ki onu var kılan sebep olmadan var olamıyorsa aynı zamanda bu sebep olmadan mümkünün bekası da düşünülemez ki bu da varlığını başkasından almasının bir gereğidir.

İmkân mefhûmunun itibari mi vucûdî ${ }^{10}$ mi olduğu da meselenin tartışılan yönlerinden olmuştur. Aslında gerçekleşmenin imkânsızlığını ifade eden istihâle' kavramının itibari olduğu noktasında doğal olarak ihtilaf yoktur. Ancak varlık ile ilişkili olan vücûb ve imkân mefhûmları söz konusu olunca bu noktada uzun soluklu kelam eserlerinde anlaşılması pek de kolay olmayan tartışmalar da yaşanmıştır. ${ }^{11}$ Bunun yanında, çalışmamızın sınırları ve gayesini aşabileceğinden muhtevasından ziyade sadece tartışmaların varlı̆̆ını zikretmek ile yetiniyoruz.

İmkân delilinin nasıl teşkil edildiğine geçmeden önce son olarak bir noktanın gözden kaçırılmaması oldukça önemlidir. Girişte de ifade ettiğimiz üzere bir şeyin, varlığında sebebe ihtiyaç duyan bir nitelikte olduğunun aklen kavranması neticesinde sebebinin varlık itibari ile kendisi ile aynı hükmü taşımaması gerektiği fikri ortak bir zemin oluştursa da bu fikrin delil olarak kullanımı her zaman aynı formda da olmamıştır. Mütekellimûn cihetine bakıldığında, mütekaddimûn devrinde fikrin daha çok "tahsîs" düşüncesi çerçevesinde işletildiğini görebiliriz. Söz gelimi “Âlemin varlığı caiz olduğu gibi yokluğu da caizdir". "Varlığı da yokluğu da caiz olanın varlığı, zatının gereği değildir". "Başka birinin tahsîsi olmaksızın, özellikle yok iken yokluğunun devamı yerine var olması düşü-

9 Mahmûd Ebû Dakîka, el Kavlü 's-sedîd fî̀ ilmi 't-tevhîd, c.1, , y.y., s.124-5.

10 Tartışmanın bu yönüne değinmeden evvel konuyu dağıtmamak adına kısaca i’tibarî ve vücûdî kavramalarının manasına kısaca değinmek yerinde olacaktır.

I’tibârî: Aklen var sayma dışında herhangi bir gerçekliği olmayan şeydir. Örneğin imkân; insan açısından ispat edilen bir manadır ancak insanın ilmi veya cehaleti gibi hariçte gerçekliği olan bir şey değildir.

Vücûdî: Hakîkî diye de tabir edebileceğimiz, dış dünyada gerçekliği olan ve var sayıma dayanmayan şeydir. Bkz. Ebû Dakîka, a.g.e, s. 128.

11 Seyyid Şerîf el Cürcânî, Şerhu'l-Mevâkıf, ( Siyalkûtî ve Halebî haşiyeleri ile birlikte), c. 3, Beyrut, Dâru'l-Kütübi'l-İlmiyye, 1998, s. 117. 
nülemez" tarzında ifadeler kullanılarak âlemden herhangi bir cüzün var oluşu hususunda hissettiği ihtiyaç, bir binanın onu yapacak birine duyduğu ihtiyaca benzetilmiştir. $^{12}$

Müteahhirûn döneminde ise imkân delili İbn-i Sînâ'nın kurgu şekli ile kullanılmaya başlamış, ilerleyen dönemlerde birçok mütekellim tarafindan etkin bir biçimde kullanılmaya devam etmiştir. Mutavvel kelam eserlerinin giriş bölümlerinde de tafsilatlı bir biçimde varlık kavramı çerçevesinde imkân, vücûb gibi kavramlar derinlemesine işlenmiştir. Bu istidlal formunda varlık kavramı merkeze alınarak varlığın vacib ve mümküne ayrıldığı, eğer zarûrî olarak kavranan bu varlık vacib ise maksadın hâsıl olduğu, değilse de geriye doğru gidildiği vakit mümkünleri varlığın dayanağı olmak bakımından birbirine isnat etmek devir veya teselsülü gerektireceğinden mutlaka varlığı zorunlu olan bir zata ulaşı1mas1 gerektiği ortaya konmuştur. ${ }^{13}$

\section{3. İmkân ve Hudûs}

İmkân ve hudûs kavramları aynı varlık kategorisi altında değerlendirilen varlıklar için kullanılsalar da aralarında farklı harf dizelerinden meydana gelmelerinin yanında göz ardı edilmemesi gereken ince bir farkın bulunduğu da unutulmamalıdır. İmkân kavramı ele alınırken gözetilmesi gereken mananın "varlığ1 yokluğuna bir olma" ve "varlık veya yokluğun; başlangıç, sonuç ya da devamı safhalarından her biri için iftikâr ve ihtiyaç halinde olması" olduğu ortaya konmaya çalışılmıştı. Hudûs kavramında ise "sebkatü'l-adem" yani varlığından önce bir yokluk geçirmiş olması anlamındaki nitelik kastedilmekte ve varlık safhasında olan bir "şey”in sahip kılındığı bu varlığının sonradanlığına işaret edilmiş olmaktadır. Kelam eserlerinin hemen tamamında yer alan âlem tanımlarında fark edebileceğimiz bu nitelik, âlem hususunda ispat edilmekte ve buradan hareketle evrenin bir yaratıcısının (muhdisi) olması gerektiği neticesine varılmaktadır. ${ }^{14}$

12 Ebu'l-Muîn en-Nesefî, et Temhîd li kavâidi't-tevhîd, tah. Muhammed Abdurrahman eş Şâğûl, Mektebetü'r-Ravza eş Şerîfe, 2006, s. 22-23.

13 Kaya, a.g.e, s. 122.

14 Fûde, a.g.e, s. 167; Ebû Dakîka hudûsun üç manası olduğunu ifade etmektedir:

Hudûs-ı Zâtî: Bir şeyin başkasına ihtiyaç duyması demektir.

Hudûs-ı Zamânî: Bir şeyin var olmadan önce yokluk geçirmesi demektir ki mütekellimlerin hudûs'tan kastettikleri mana da bu nevidir.

Hudûs-ı İzâfî: Daha çok lügat manasında olup zamansal açıdan yeni oluşu ifade etmektedir. Bkz. el Kavlü's-sedîd fì ilmi't-tevhîd, s. 142. 
Bu iki mefhûm arasında göze çarpacak olan en önemli fark imkân mefhumunun bir şey hakkında varlığa çıkmış olup olmadığına bakılmaksızın da kullanılabilecek oluşudur. Zira bir şey var olmadan evvel de onun hakkında imkândan söz edilebilir ancak hudûs böyle değildir. Varlık sahasına çıkmayan bir şey için hudûs diye bir şey söz konusu olamaz ki hudûs zaten varlığından önce yokluk geçiren hakkında kullanılır. Ancak varlık tahakkuk ettikten sonra da imkân durumu aynı şekilde devam eder. Bunu da şu şekilde formülize edebiliriz; "her hâdis mümkün'dir ancak her mümkün hâdis değildir." Bu ayrımın bir gereği olarak delillendirme yönünden de bir farklılık meydana gelmektedir.

İmkân delili kullanılırken küllî bir kavram olarak varlık mefhûmu ele alınmakta ve bu varlığın mümkün veya zorunlu oluşu sorgulanarak delilin hedefi olan zorunlu varlığın gerekliliği neticesine ulaşılmaktadır. Zorunlu varlıktan varlık itibari ile farklı olduğu ortaya konmuş olan âlemin zamansal açıdan başlangıcı olup olmadığı hususu ise imkân delili ile ulaşılması hedeflenen bir netice değildir. Hâlbuki hudûs delilinde öncelikle âlemin yaratıldığg yani varlığının bir başlangıcının olduğu ispat edilmeye çalışılırken bu bilgi bir öncüle dönüştürülerek söz konusu başlangıcı gerçekleştiren bir muhdisin olması gerektiği sonucuna ulaşılmaktadır. ${ }^{15}$

\section{2. İmkân Delili İle Alakalı Meseleler}

\section{1. İmkân Delilinin Akaid Sahasında Kullanımı}

İlk bölümde imkân mefhûmu ile alakalı meselelerden bahsetmemizin ardından ilk olarak imkân delilinin kullanımının kelam eserlerinin hangi bölümlerinde yoğunlaştığına değinmek istiyoruz. Böyle bir başlık açmamızın nedeni ise teorik olarak oluşumundan bahsettiğimiz imkân delilinin pratik olarak hangi bölümlerde kullanıldığını tespit ederek hem doğrudan ilgililerin delile ulaşmasını kolaylaştırmak, hem de söz konusu bölümler okunduğunda okuyucuda delil hususunda bir farkındalık oluşmasını sağlamaktır.

Yukarıda imkân delilinin kullanımının İbn-i Sînâ'nın tesirinden önce ve sonra olarak değerlendirdiğimizde form olarak farklı olduğuna değinmiştik. Bu minvalde İbn-i Sînâ'dan sonraki kelam eserlerinde "Allah'ın varlığının bilinmesi" başlığı altında açılan bölümlerde bu bilginin ya hudûs ya da imkân yoluyla elde edileceği ortaya konarak bu delillerin işletilmesi suretiyle matluba erişilmeye ça-

15 Fûde, a.g.e, s. 156. 
lışılmıştır. ${ }^{16}$ Bizi dönemsel olarak farklılık olduğu şeklindeki değerlendirmeye sevk eden sadece delilin bu başlık altında değerlendirilmesi değil, bilakis hareket noktasının salt varlık mefhûmu olmasıdır. Bu özel başlığın yanında kıdem, beka, kıyâm bi nefsihî gibi sıfatların isbatı için ayrılan bölümlerde imkân mefhûmunun kullanıldığını görebiliriz. Mütekaddimûn devrinde ise imkân mefhûmunun, ruhu itibari ile bir farklılık olmaksızın "tahsîs" düşüncesi çerçevesinde yukarıda ismi geçen bâblarda yaratıcı ile yaratılmışlar arasındaki her türlü benzerliği giderilmesi yönünde kullanıldığgnı görebiliriz. ${ }^{17}$

Bu mefhûmun yaratıcının kadim ve baki oluşunu ispat için kullanılıyor olmas1 apaçıktır. Zira kıdem zaten varlığın bir başlangıcının olmaması demek olduğundan, kadim olduğu ispat edilmek istenen zattan, herhangi bir zaman diliminde var olmama ihtimalinin zihnen veya haricen iptal edilmesi yönünden imkân mefhûmuna müraccat edilmektedir. Bunun ardından da beka sıfatının ispatına çalışılmaktadır ki zaten kıdem ispat edildikten sonra beka da kendiliğinden sübût bulur. Zira varlığının bir öncesi olmayan yani varlı̆̆ kendinden olan bir zatın herhangi bir anda yokluğu da düşünülemez. ${ }^{18}$ Kıyâm bi nefsihî de yaratıcının varlığının kendinden kaynaklanması ve var olma hususunda başkasına dayanmamas1 gerektiği manasını ihtiva etmektedir. Bu sebeple imkân mefhûmu yaratıcıdan nefyedilerek onun hiçbir şeye ihtiyaç içinde olmadığı ispatlanmaya çalışılmıştır.

\section{2. İmkân Delilinde Hasmı Kabule Zorlayan Akli İmkânsızlıklar}

\subsubsection{Devir}

Bir mantık terimi olarak devir, ispatı birbirine bağlı iki önerme ve birinin varlığı diğeri ile bağlantılı iki şart arasındaki ilişki anlamına gelir. Devir günümüz Türkçesinde döngü ve kısır döngü gibi ifadelerde karşılık bulurken batı dilinde-

16 İbnü't-Tilmisânî, Şerhu'l-meâlim fì usûli'd-dîn, tah. Nizâr Hammâdî, Kuveyt, Dâru'z-Ziyâ, 2012, s.38. Gazzâlî, el İktisâd fi'l-İtikâd adlı eserinin girişinde "da'vâ", "matlab veya "matlûb" ifadelerini her ne kadar aynı şahıs tarafından aynı gaye ile ortaya konmaya çalışılan önermeler için kullanılsalar da itibarları bakımından farklı durumlarda kullanıldıklarını ifade etmektedir. Eğer ortada bir hasım var ise kişinin isbata çalıştığı görüşü da'vâ; eğer ortada bir hasım yok ise matlab olarak isimlendirildiğini ifade etmektedir.

17 Ebû Bekir el-Bâkıllânî, Kitâbu't-Temhîd, Beyrut, Menşûrâtü Câmiati'l-Hikme fî̀ Bağdâd (Silsiletü ilmi'l-kelâm), el Mektebe eş- Şarkıyye, 1959, s. 24.

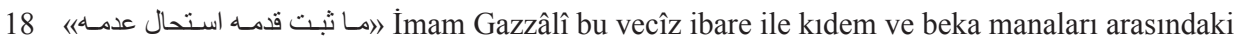
alakayı ortaya koymaktadır. Bkz. el İktisâd fi'l-I'tikâd, s. 144, Herhalde kelam eserlerde beka sıfatının kıdem sıfatından sonra zikredilmesi de bu sebepledir. Kıdem sıfatı tabiatıyla beka sıfatını da gerekli kılmaktadır ancak beka kıdemi gerektirmez. Zira varlığı kendinden olan zat dilediği takdirde mümkünün varlık sebebini sonsuza kadar devam ettirip onu ebedî kılabilir ki cennet, cehennem ve ehlinin ebediliği bu kabildendir. 
ki karş1lığ ise totolojidir. ${ }^{19}$ Devrin birçok türünden bahsedilmek ile birlikte aklî olarak imkânsızlığa götürdüğü yönü ile ele alınan türü devr-i tekaddümîdir. ${ }^{20}$

Devrin bu nevinin imkânsızlığa sevk eden tarafı ise bir şeyin aynı zamanda hem var hem de yok olması gibi bir neticeyi gerektiriyor oluşudur. Örneğin A ile B arasında birbirilerinin varlık sebebi olma açısından bir alakanın var olduğu düşünülse, B'nin sebebi olması bakımından A mutlaka B'den önce var olmalıdır. Ancak B'nin kendisinin varlık sebebi de olduğunu düşündüğümüzde B'den mutlak surette sonra var olmalıdır. Yani aynı zamanda hem var hem de yok olması gibi hiçbir şekilde düşünme gibi bir zahmete mahal bırakmayacak derecede apaçık bir çelişki meydana gelmektedir. ${ }^{21}$

\subsubsection{Teselsül}

Lügat manası olarak nihayetsiz şeyler dizesi olan teselsül22, bizatihi mümkün olan şeylerin sonsuza kadar devam edişinden ibarettir. Prensip olarak teselsülün kabulü ile alakalı görüşlerin de üç noktada temerküz ettiğini söyleyebiliriz. Birinci görüş, Cehm b Safvan ve Ebü’l-Hüzeyl el Allâf ve takipçilerinin tebennî ettiği hem mazide hem de gelecekte teselsülün mümkün olmadığı düşüncesidir. Mütekellimlerin büyük çoğunluğunu yansıtan ikinci görüşe göre geriye doğru teselsül imkânsız olup geleceğe yönelik olarak varlık verenin varlı̆̆ devam ettirmesi ile teselsül mümkündür. Üçüncü görüş ise Selefiyye ile İslam filozoflarının büyük çoğunluğuna ait olup hem geriye hem de ileriye dönük olarak teselsülün imkânını kail olmayı gerektirir. ${ }^{23}$

19 Metin Yurdagür, "Devir”, DİA, c. 9, 1994, s. 230-231, Cürcânî devri mutlak olarak “ Bir şeyin bağlı olduğu şeye bağlanması" anlamındaki tevakkufu'ş-şey' alâ mâ yetevakkafu aleyh ibaresi ile tarif etmiştir. Ancak biz Yurdagür'ün ifadeleri meramımızı daha açık bir şekilde ifade ettiğinden yukarıda onlara yer verdik. Bkz. Cürcânî, a.g.e, s. 92.

20 A. ml, s. 230. Aklen imkânsızlığa sevk eden bu çeşidinin yanında birinin tasavvurunun diğerinin tasavvurunu da zorunlu kıldığı izafî devir de bulunmaktadır ki buna devr-i ma'î de denmektedir ve bu devir mantıkî açıdan bir problem teşkil etmemektedir. Konumuzun başında imkân, vücûb ve istihâle' kavramlarını tarif ederken yaşanan devir de bu kabildendir. Zira bu üç kavramı birbirinden bağımsız olarak tasavvur edilemez.

21 Celâlüddîn ed-Devvânî, Risâle fî isbâti'l-vâcibi'l-kadîme, Sebu'Resâil, dzn. Dr. Seyyid Ahmed et-Tûsirkânî, Tahran, Miras Mektûb, 1979, s. 69.

22 Cürcânî, a.g.e, s. 53.

23 Osman Demir, “Teselsül”, DİA, c. 40, 2011, s. 536-538, İslam filozofları ile Selefiyye'nin teselsülü caiz görmesi âlemin kıdemi ile alakalıdır. Yoksa varlığı kendinden olmayan mümkünler silsilesinin sonsuza dek sürmesi ve silsilenin zorunlu bir varlıkta durmaması anlamında değildir. 


\subsubsection{Tercîh bilâ muraccih}

Mümkünün varlık veya yokluk ihtimalleri aklen tasavvur edilebilir olduğundan bu ihtimallerden herhangi birinin mümkünün zatından kaynaklanmadığ1 ortaya çıkmış olur. Dolayısıyla varlık ihtimalinin gerçekleştiği varsayılırsa bu ihtimalin gerçekleşmesi mutlak surette bir müreccih sayesinde olmalıdır. Varlığın başlangıcı bakımından geçerli olan bu tercih, mevcûdun sahip olduğu cismî özellikleri gibi her türlü vasfı için de geçerli olmalıdır. Zira insanın sahip olduğu uzunluk-kısalık, deri rengi vs. hususiyetleri ilk bakışta zıtları ile muttasıf olmasını aklın onayladığı niteliktedir. Buradan da hem yokluğun yerine varlığın hem de aklî imkân dairesindeki zıtlarının yerine muayyen hususiyetlerinin tahakkuk etmiş olmasının mümkünün zatı dışındaki bir müreccihin tercihi ile gerçekleştiği anlaşılmış olur. ${ }^{24}$

Hem varlığı hem de tüm hususiyetleri bakımından tercihe maruz olan mümkün için bu ihtimalleri gerçekleştirecek zatın ise zorunlu bir varlık olması gereklidir. Zira bu tercihi zorunlu olan bir varlığın gerçekleştiği söylenmezse kendisi gibi mümkün yani tercihe maruz olan bir zatın gerçekleştirdiğinin söylenmesi gerekecektir. Bu durumda yukarıda da ifade edildiği üzere aklen geçersiz olan devir ve teselsül ihtimalleri gerekeceğinden müreccihin mümkün kategorisindeki bir zat olması düşünülemez.

\section{3. İmkân Mefhûmunun İslam Filozofları ve Mütekellimler Arasında Delil Olarak Kullanımı}

Çalışmamızın ana hatlarından birini oluşturan bu kısma giriş yapmadan önce başlıkta kullandığımız "İslam filozofları" ibaresini biraz açmamız gerekmektedir. Zira burada kastımız bu mefhûmun içine girebilecek tüm filozoflar değildir. İslam felsefesinde alem-tanrı tasavvuru noktasında birbirinden farklı izah tarzlarına rastlamak mümkündür. Ancak bu tabire az çok aşina olan herkesin aklına gelen ilk kesim herhalde "Meşşâiyye" olsa gerektir. Özellikle de Gazzâlî ve Râzî ile birlikte kelam geleneğinde reddiyelere maruz kalan ve Tehâfütü'l-felâsife adlı eserinde dillendirdikleri bazı görüşleri nedeniyle Gazzâlî tarafından tekfîr edilenler meşşâî filozoflar olmuştur. ${ }^{25}$

24 Nesefî, Tebsıratü'l-edille, tah. Hüseyin Atay, Diyanet İşleri Başkanlığı Yayınları, s. 107.

25 Gazzâlî, Tehâfütü'l-felâsife, çev. Mahmut Kaya, İstanbul, Klasik Yayınları, 2014, s. 10. İmam Gazzâlı̀’nin filozofları tekfîr ettiği hususlar üç noktada toplanmaktadır;

1. Âlemin ezeliliği

2. Haşrın cismânî oluşunu reddetmeleri

3. Allah'ın (c.c.) cüz'îleri bilmesini reddetmeleri. 
Meşşâî felsefe temsilcilerinin âleme bakışlarındaki ortak nokta ise -İbn-i Rüşd ve Kindî istisnâ tutulursa- alemin kadîm olduğu ve zamansal anlamda Allah (c.c.) ayrılmadığı hususudur. ${ }^{26}$ Zaten imkân delili ile alakalı olan ve ele almaya çalışacağımız mesele âlemin kıdemidir. Meşşâi filozoflar arasında ortak payda olan âlemin kadîm oluşu ve imkân delilinin bu paydaya nasıl katkı sağladığını izah ederek, mütekellim perspektifinin delile nasıl bir yaklaşım getirdiğini belirlemeye çalışacağız. Özellikle de Meşşâî düşüncenin en olgun evresinin temsilcisi ve de kelam-felsefe münasebeti denince "makul-i evvel” olan İbn-i Sînâ'nın yaklaşımını ele alıp mahiyetini tespit etmeye çalışacağız.

Bazı çevrelerde filozofların delili olarak dillendirilen ${ }^{27}$ imkân delilinin daha önce asgari mefhûm olarak, bir varlık hakkında "iftikar" düşüncesinin fark edilmesini içerdiğinden bahsetmiştik. Ancak İbn-i Sînâ'dan sonra mütekellimler nezdinde hem delilin formunun hem de kullanım yoğunluğunun değiştiği de su götürmez bir gerçektir. Daha çalışmamızın başında imkân mefhûmun zaruri bir kavram olduğunu ortaya koymaya çalışırken gayemiz, bu mefhûmun delil değerine işaret etmek için idi. Bununla beraber delilin asıl gayesinin de zorunlu varlığa erişmek olduğundan bu neticenin hâsıl olması itibari ile bir farkın olmadığını da söyleyebiliriz. Zira İbn-i Sînâ'nın kurgusu mütekellimler tarafından da kullanılmaktadır. Ancak filozoflar ile mütekellimlerin mümkün varlıktan anladıkları, âlemin var oluşu ve Allah'ın (c.c.) âlem ile olan irtibatına bakışları aynı değildir.

Said Fûde problemin bu yönüne Siyalkûtî'den yaptığı şu nakilde işaret etmektedir:

“Filozofların gayesi hudûs veya imkân'ın ispatından uzaktır. Zira onlar âlemden münezzeh olan vacibu'l-vücûd'u ortaya koymaktadırlar hâlbuki bu varlığın âlemin "yaratıcısı" olması ise başkadır."28

Tahakkuk etmiş bir varlık mefhûmundan hareket edilen imkân delilinde artık mesele nazari boyutta ele alınmamaktadır. Dolayısı ile mütekellim açısından mümkün varlığı hâdis oluşundan bağımsız olarak düşünmek söz konusu değildir. İki farklı âlem tasavvuruna göre mesele şu merhaleye intikal etmiş bulunmaktadır; varlığı kendinden olmayan ve dolayısı ile mümkünü'l-vücûd olan alem, yoktan mı var edilmiş̧ir yoksa zamansal olarak bir başlangıcı yok mudur? Bu soruya vereceğimiz cevap imkân delilinin kullanımındaki gayenin, mefhûm olarak imkân'a bakıştan dolayı farklı olduğunu gösterecektir.

26 Mahmut Kaya, "Meşşâiyye”, DIA, c. 29, 2004, s. 393-394.

27 Bekir Topaloğlu, İsbât-ı Vâcib, Diyanet Vakfı Yayınları, 1979, s.120.

28 Fûde, a.g.e, s. 104. 
O halde zorunlu varlığa ulaşma açısından bir fark olmasa bile mütekellimlere göre Allah (c.c.) ile âlem arasındaki ilişki Meşşâi düşüncesindeki gibi illet-malul ilişkisi değil bilakis "yaratma" ilişkisi olmalıdır ve mümkün'ün varlığının bir başlangıcı olmalıdır. Yani mümkün'ün imkânının ispatı Allah'ın (c.c.) kıdem sıfatında müstakil oluşu anlamına gelmektedir. Hâlbuki âlemin kıdemi öncülü söz konusu olduğunda varllğı kendinden kaynaklanmasa da mümkünün ezelî oluşunda bir sakınca yoktur.

İbn-i Sînâ'nın meseleye getirdiği yaklaşımı ise varlık-mahiyet ayrımı bakımından izah etmeye çalışacağız. Mümkün olan varlıkta vucûd ile mahiyetin ayrı olduğu, zorunlu varlıkta ise bir olduğu düşüncesi ile tanrı-âlem ilişkisini ortaya koyan bu ayrımın daha önce Fârâbî'de de görüldüğüne ilişkin tezler bulunmak ile birlikte bu teori İbn-i Sînâ'da bir sistem haline dönüşmüştür. ${ }^{29}$ İbn-i Sînâ, mütekellimlerin kullanmış olduğu hudûs delilini zayıf bularak çeşitli yönlerden eleştirmiş ${ }^{30}$ ve zorunlu-mümkün ayrımına dayanan imkân delili formunu kullanmıştır.

İbn-i Sînâ'nın hudûs deliline yönelik eleştirisinin sebebi ise âlemin zamansal olarak bir başlangıcının olduğu iddiasını taşımasıdır. Bundan dolayıdır ki mümkün mefhûmunu mahiyet-varlık ayrımına tabi tutarak mahiyetlerin ezelde Allah (c.c.) ile beraber var olduğunu ancak zatları itibari ile var olmaları gerekmediğinden varlığın kendilerine arız olduğunu söylemektedir. Yani âlem varlık kazanırken zamansal anlamda bir yokluktan sonra var olmuş değildir bilakis ezelden beri var olan mahiyetlere zorunlu varlık tarafindan varlık sudur etmiştir. Böylece kendilerinde varlık-mahiyet ayrımı bulunan mümkünlerde asıl olan mahiyet, araz olan ise varlık olmaktadır. ${ }^{31}$

İbn-i Sînâ bu şekilde Tanrı ile âlem arasındaki farklı1ığı sebeplilik ile ortaya koyarken aynı zamanda sudur teorisine uygun olarak varlığı da izah edebilme bakımından kendine alan açmış olmaktadır. Görüldüğü üzere imkân delili, hudûs delilinde olduğu gibi içerisinde bazı kavramları barındıran önermelerden ibarettir.

29 Fadıl Alğan, "Zorunlu Varlığı İspat Bağlamında İbn-i Sînâ'da Varlık- Mahiyet İlişkisi”, Siirt Üniversitesi İlahiyat Fakültesi İslami İlimler Dergisi, cilt 10, say1 1, Bahar, 2015, s. 113.

30 Muhammet Fatih Kılıç, "İbn-i Sînâ'nın Kelamcıların Hudûs Deliline Yönelttiği Eleştiriler”, Divan Disiplinler Arası Çalışmalar Dergisi, cilt 15, sayı 28, 2010, s. 115-134. Yazar bu eleştirileri dört maddede özetlemektedir: Âlem hâdistir öncülünün zayıf olduğu, Delilin Tanrı'ya olan ihtiyacı açıklamadaki yetersizliği, hâdisin varlığını sürdürmesini açıklamadaki yetersizliği, Tanrı'nın münezzehliğine halel getirmesi.

31 Mehmet Cüneyt Kaya, "İslam Felsefesinde Metafizik Bir Problem Olarak İmkân", (Yayımlanmamış Doktora Tezi), İstanbul Üniversitesi Sosyal Bilimler Enstitüsü, İstanbul, 2008, s. 193. 
Önermenin varmak istediği neticeyi doğru görebilmek için de kullanılan kavramların içinin iyice doldurulması gerekmektedir. Böyle olduğu takdirde mütekellim perspektifi ile meşşâi perspektif arasındaki farkın anlaşılabileceği kanaatindeyiz. İki şey arasındaki başkalığ1 (gayriyyet) görebilmenin ön koşulunun o iki şeyi olduğu gibi anlayabilmek olduğu ise izahtan varestedir.

Meşşâ̂ felsefenin âlemin kadim oluşuna dair iddiasına mütekellimler tarafindan çeşitli yollar ile itirazlarda bulunularak teselsülün geçersizliği sadedinde bazı deliller ortaya konulmuştur. Bu delillerin en meşhurları burhân-1 tatbîkî, burhân-1 tezâyüfî̀ ve burhân-1 arşî’dir. Mezkûr burhan çeşitlerinin mahiyetine kısaca değinip faslımızı nihayete erdirmek istiyoruz.

\subsubsection{Burhân-ı Tatbîkî}

İki tane sonsuz dizi farz ettiğimizde birincisini bize doğru olan son malülden ikincisini de bir üstteki malülden başlatıp çakıştırdığımızı düşünelim. Birinci dizinin ikinci halkası ikinci dizinin birinci halkasına denk gelmiş olur ve dolayısıyla dizeler arasında belirli miktarda fazlalık ya da noksanlığın olması gerekir ki sonsuz olan şeyler arasında fazlalık ya da azlık söz konusu olamaz bu da ikisinin de sonsuz olmadığını ve bir noktada durmaları gerektiğini gösterir. ${ }^{32}$ İmam Gazzâlî gezegenlerin hareketlerinin sonsuz olduğunu iddia eden filozoflara karşı bu delili işletmektedir:

“ Onlara göre Venüs dönüşünü otuz senede tamamlamakta, güneş ise dönüşünü bir sene zarfinda tamamlamaktadır. Dolayısı ile Venüs’ün deveranı Güneş’inkinin otuzda birine denk gelmektedir. Zira Venüs otuz senede bir kere dönebilir iken Güneş bu süre zarfinda otuz kere dönmektedir. Bir ile otuz arasındaki fark da ortadadır. Sonra Venüs, Güneş’ten daha az dönmesine rağmen ikisinin de deveranı- iddialarına göre- sonsuzdur. Bir şeyin otuzda birinin o şeyden daha az olduğu ise apaçıtır. Ay da bir senede on iki sefer dönmektedir bu da Güneş'in deveranının Ay'ınkinin on ikide biri olduğunu gösterir. Hâlbuki biri diğerinden daha az olduğu halde ikisinin de sonsuzluğu iddia edilmektedir ki bu imkânsızdır". ${ }^{33}$

\subsubsection{Burhân-ı Tezâyüfî}

$\mathrm{Bu}$ burhan formu, malül sayısının illet sayısından bir fazla olması gerektiği fikrine dayanmaktadır. Sonsuz bir dizi farz ettiğimizde her halka, kendinden öncekine göre malul kendisinden sonrakine göre illet konumundadır. Hâlbuki dizi-

32 Devvânî, a.g.e, s. 96.

33 Gazzâlî, a.g.e, s. 140-141. 
nin son halkası sadece maluldür ki bu da dizide malul sayısının bir fazla olduğunu gösterir. Cüzleri içerisinde fazlalık ya da noksanlık bulunan bir şey de sonsuz olamaz. $^{34}$

\subsubsection{Burhân-ı Arşî}

Yine sonsuz bir dizi farz edildiği takdirde dizinin bize doğru en son halkasından herhangi bir illete kadar olan kısmın çıkarıldığında çıkarılan kısım miktar olarak kalan kısımdan daha az olacaktır. Bir şeyden miktar olarak daha az veya daha çok olan bir şeyin de sonsuz olması düşünülemez. ${ }^{35}$

\section{Ek: \\ İmkân Mefhûmunun Delil Olarak Kullanımına Örnekler \\ Platon:}

Bazı şeyler kendiliğinden hareketlidir. İki türlü hareket söz konusudur: Başka bir şey vasıtası ile hareket ve kendiliğinden hareket. Başkası vasıtası ile hareket kendiliğinden hareketin varlığını akla getirir; zira hareketli varlıklar hareketlerinin kaynağı olan kendiliğinden hareketli bir varlığı gerektirir; aksi takdirde -başkası tarafindan hareket ettirilen varlıklar bir ilk muharrike ihtiyaç duyduklarından- hareketin başlangıç noktası olmazdı. Ve şayet her şey sükûn halinde olsaydı, - başkası tarafından hareket ettirilen şey, başka bir hareketli varlığı gerektireceğinden-, böyle bir durumda ancak kendiliğinden hareket ortaya çıkabilirdi; bu ise her şeyin sükûn halinde olması varsayımına aykırıdır. Dolayısıyla, tüm hareketin kaynağ 1 "kendiliğinden hareketli olan varlık" veya "ruh"tur. ${ }^{36}$

\section{Ebû Nasr el-Fârâbî:}

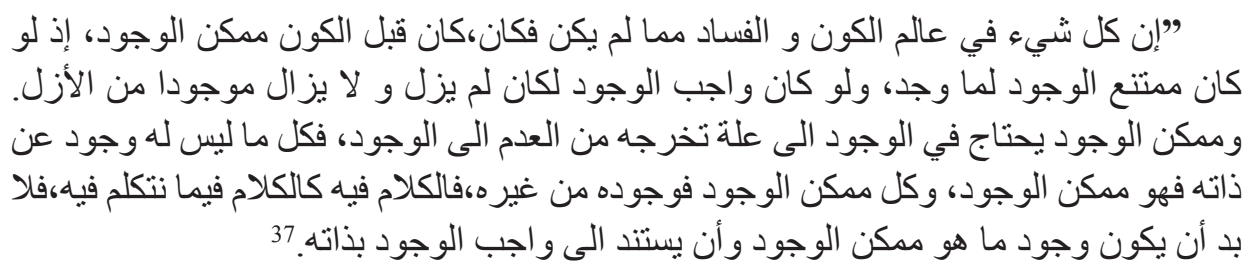

34 Demir, A.md., s. 536.

35 Demir, A.md., s. 537-538.

36 Ulvi Murat Kılavuz, "İslam Kelâmında Kozmolojik Delil”, (Yayımlanmamış Doktora Tezi), Uludağ Üniversitesi Sosyal Bilimler Enstitüsü, Temel İslam Bilimleri ABD, Kelâm BD, Bursa, 2007, s. 17.

37 Fûde, a.g.e, s.105 


\section{İbn-i Sînâ:}

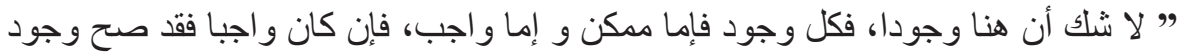

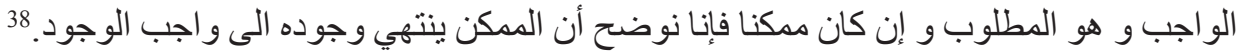

\section{Ebû Reşîn en Nîsâbûrî:}

Kadîm ya vâcibü'l-vücûd'dur ya da câizü'l-vücûd'dur. Eğer câizü'l-vücûd olsa, varlığın yokluğa ağır basması ancak bir var edici sebebiyle olur. Var edici ile öncelenen bir şey kadîm olamaz. Çünkü kadîm varlığının başlangıcı olmayan demektir; öyleyse bir var edicinin onu var kılması söz konusu olamaz. Bu durumda onun câizü'l-vücûd olması mümkün değildir. Vâcibü'l vücûd'a ise kat'î surette yokluk ilişmeyecektir. ${ }^{39}$

\section{Ebu'l-Meâlî el Cüveynî:}

الحادث جائز وجوده وانتفاؤه، وكل وقت صادفه وجوده كان من المجوزات تقدمه عليه

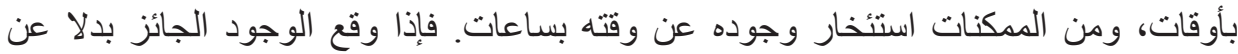

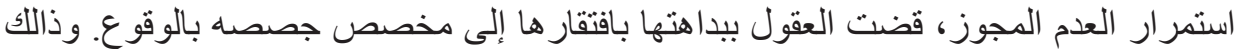

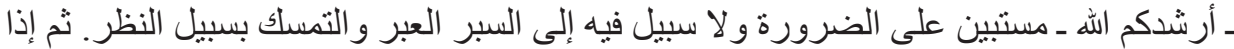

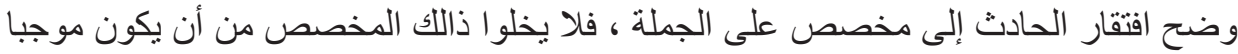

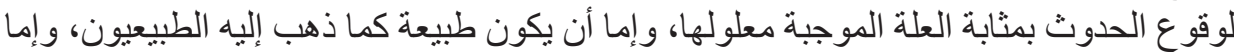

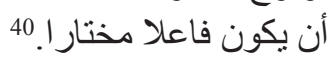

\section{Fahruddîn er-Râzî:}

إمكان الذو ات : لا شك في وجود موجود فهذا الموجود إن كان و اجبا لذاته فهو المقصود،وو إن

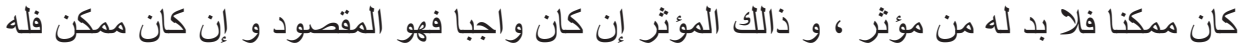

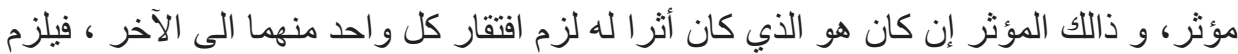

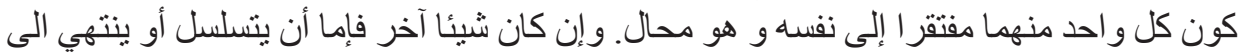

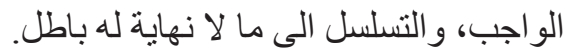

إمكان الصفات : قد دللنا على أن الأجسام بأسر ها متساوية في تمام الماهية، و إن كان كذالك إنا

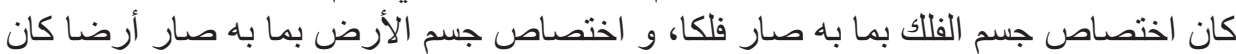

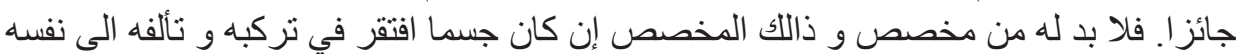
فهو محال، و إن لم يكن جسما فهو المطلوب دالـ

38 Fûde, a.g.e, s. 110.

39 Kaya, a.g.e, s. 92-93.

40 İmâmü'l-Harameyn Ebu'l-Meâlî el Cüveynî, Kitâbü'l-İrşâd, Misır, Mektebetü'l-Hâncî, 1950, s. 28

41 İbnü’t-Tilmisânî, Şerhu Meâlimi usûli'd-dîn, s. 39-40. 


\section{Leibniz:}

- Bir şey vardır.

- Hiçbir şeyin var olmaması yerine bir şeylerin olmasının mutlaka bir yeter sebebi aklî temellendirmesi olmalıdır.

- Bu yeter sebep herhangi münferit bir varlıkta, varlıkların mecmuunda veya varlıkların etken sebeplerinde bulunamaz

- Dolayısı ile bu âlemin ve onun hallerinin dışında ve ötesinde alemin bir yeter sebebi bulunmalıdır.

- $\mathrm{Bu}$ yeter sebep, metafizik olarak zorunlu bir varlık yani, varlığının yeter sebebi kendisinde bulunan ve bu sebebi dışarıdan almayan bir varlık olmalıdir. ${ }^{42}$

\section{Sonuç}

Bu çalışmamızda öncelikle tarih boyunca varlığın izahı yönünde çaba sarf eden önemli simalar arasındaki asgari müşterek manayı yakalamaya ve imkân delilini bu çerçevede ele almaya çalıştık. Bahsedilen asgarî mananın ise bir şeyin varlığa çıkma hususunda ihtiyaç ve iftikar içerisinde bulunması, yani varlığının başkasına dayanması gerektiğinin fikrinin olduğu sonucuna vardık. imkân diye adlandırılan bu mananın daha iyi anlaşılabilmesi için öncelikle vücûb ve istihâle gibi kavramaların muhtevasından da bahsederek, bu kavramların birbirinden ayrı olarak tasavvur edilemeyeceğinden bahsettik. Kavramların arasındaki ayrılmaz alakanın sebebinin de bedîhî olarak idrak edilen "varlık" mefhûmu olduğunu tespit ettik. Ayrıca imkân ile hudûs mefhûmları arasındaki ortak noktaları ve fark11lıkları belirlemeye çalıştık. Bir kavram olarak imkânın zihinde hudûstan önce bulunduğunu ve bu manada hudûstan daha geniş bir kavram olduğunu gördük.

Kavramsal altyapıyı oluşturmaya çalıştığımız bu kısımdan sonra imkân mefhûmunun kelâm eserlerinin hangi bölümlerinde delil olarak kullanıldığını tespit etmeye çalıştık. Bununla bir yandan ilgililerin delile ulaşımını kolaylaştırıp, öbür yandan yapılan okumalar esnasında bu anlamda bir farkındalık oluşmasını hedefledik. Akabinde imkân mefhûmu anlaşılmadığı takdirde kişiyi kabule zorlayan devir, teselsül ve tercîh bilâ muraccih gibi akî imkânsızlıkların meydana geleceğini ifade ettik.

İslam düşünce geleneğinin en önemli temsilcilerinden olan İslam filozofları ile mütekellimler de bu mefhûmu delil olarak kullanmışlardır. Bu mefhûmun 
delil olarak kullanımında iki grup arasında ne gibi farklılıklar veya ortak noktalar olduğunu belirlemeye çalıştık. Yaptığımız mukayesede İslam filozoflarının tamamını değil, alemin kıdemini kâil olan Meşşâiyye ekolünü esas aldık. Meşşâi felsefenin imkân mefhûmuna ve mümküne bakışlarının illet-malul ilişkisi ve alemin kıdeminden bağımsız olarak değerlendirmesinin doğru olmadığını ifadeye çalıştık. Bu arka planın özellikle İbn Sînâ'da sistemleşen vucûd-mâhiyet ayrımı ile zirvesine ulaştığına ve daha açık bir şekilde göründüğüne şahit olduk. Mütekellimler ise tam aksine alemin hudûsu ve Allah'ın(c.c.) kıdemde biricik olduğu olduğu arka planında delili işletmişler ve aradaki en bariz fark da bu olmuştur. Mütekellimlerin mütekaddimûn devri temsilcilerinde delil tahsîs formunda kullanılırken, İbn Sînâ sonrasında varlık mefhûmunun merkeze alındığ form kullanılmaya başlanmıştır. Delilin asıl gayesi olan "zorunlu varlığa ulaşma" açısından bir fark olmasa da asıl dikkat çekmek istediğimiz nokta imkân delilinin öncüllerinin iki düşüncenin sahip olduğu fikri alt yapıya göre değerlendirilmesinin gerekliliği idi.

Son olarak da mefhûmun farklı zümreler nezdinde kullanımlarını görebileceğimiz örnek metinleri sunarak okuyucunun bizzat tahlil edebilmesine imkân sağlamayı amaçladık. 


\section{Kaynakça}

Alğan, Fadı1, “Zorunlu Varlığı İspat Bağlamında İbn Sînâ'da Varlık- Mahiyet İlişkisi”, Siirt Üniversitesi İlahiyat Fakültesi İslami İlimler Dergisi, c. 10, sayı 1, Bahar, 2015.

Bâkıllânî, Ebû Bekir, Kitâbu 't-Temhîd, Beyrut, Menşûrâtü- Câmiati'l-Hikme fî Bağdâd (Silsiletü İlmi'l-Kelâm), el Mektebe eş- Şarkıyye, 1959.

Bolay, M. Naci, "Bedihi”, DIAA, c. 5, 1992.

Cürcânî, Seyyid eş Şerîf, Mu'cemu't- Ta'rifât, tah. Muhammed Siddîk el Minşâvî, Dâru'l-Fazîle.

, Şerhu'l-Mevâkıf, (Siyalkûtî ve Halebî haşiyeleri ile birlikte), Beyrut, Dâru'l-Kütübi'l-İlmiyye, 1998.

Cüveynî, İmâmü'l-Harameyn Ebu'l-Meâlî, Kitâbü̈'l-İrşâd, Misır, Mektebetü'l-Hâncî, 1950.

Demir, Osman, “Teselsül”, DIA, c. 40, 2011.

Devvânî, Celâlüddîn, Risâle fì İsbâti'l-Vâcibi'l-Kadîme, Sebu' Resâil, dzn. Dr. Seyyid Ahmed et- Tûsirkânî, Tahran, nşr, Miras Mektûb, 1979.

Ebû Dakîka, Mahmûd, el Kavlü 's-Sedîd fì İlmi't-Tevhîd, tah. Avadullâh Câd Hicâzî, y.y.

Fûde, Said Abdüllatîf Mahmûd, “el Edilletü'l-Akliyye li Vucûdillah (Beyne'l-Felâsife ve'l-Mütekellimîn)", (Yayımlanmamış Doktora Tezi), Amman Uluslararası İslam Üniversitesi Yüksek İhtisas Fakültesi Usûlü'd- Dîn Kısm1, Amman, 2014.

Gazzâlî, Huccetü'l-İslam Muhammed b Muhammed, el İktisâd fi'l-İ'tikâd, Dâru'l-Minhâc, 1437. lar1, 2014.

, Tehâfütü'l-felâsife, çev. Mahmut Kaya, İstanbul, Klasik Yayın-

İbnü't-Tilmisânî, Şerhu, Meâlimi usûli'd-dîn, tah. Nizâr el Hammâdî, Kuveyt, Dâru'z- Ziyâ, 2012.

Kaya, Mahmut, "Meşşâiyye”, DİA, c. 29, 2004.

Kaya, Mehmet Cüneyt, "İslam Felsefesinde Metafizik Bir Problem Olarak İmkân”, (Yayımlanmamış Doktora Tezi), İstanbul Üniversitesi Sosyal Bilimler Enstitüsü, İstanbul, 2008.

Kaya, Veysel, "Felsefî Kelam Çerçevesinde İbn-i Sînâ’nın Kelam’a Etkileri”, 
(Yayımlanmamış Doktora Tezi), Uludağ Üniversitesi Sosyal Bilimler Enstitüsü Temel İslam Bilimleri Anabilim Dalı Kelâm Bilim Dalı, Bursa, 2013.

Kılavuz, Ulvi Murat, "İslam Kelâmında Kozmolojik Delil”, (Yayımlanmamış Doktora Tezi), Uludağ Üniversitesi Sosyal Bilimler Enstitüsü Temel İslam Bilimleri Anabilim Dalı Kelâm Bilim Dalı, Bursa, 2007.

Kılıç, Muhammet Fatih, "İbn-i Sînâ'nın Kelamcıların Hudûs Deliline Yönelttiği Eleştiriler”, Divan Disiplinler Arası Çalışmalar Dergisi, cilt 15, sayı $28,2010$.

Nesefî, Ebu'l-Muîn, Tebsıratü'l-Edille fì Usûli'd- Dîn, tah. Hüseyin Atay, Ankara, Diyanet İşleri Başkanlığı Yayınları, 1993.

, et Temhîd li Kavâidi 't-Tevhîd, tah. Muhammed Abdurrahman eş Şâgûl, Mektebetü'r-Ravza eş Şerîfe, 2006.

Fahruddin Ömer er-Râzî, Nihâyetü'l-Ukûl fì Dirâyeti'l-Usûl, tah. Saîd Abdüllatîf Mahmûd el Fûde, Beyrut, Dâru'z- Zehâir, 2015.

Topaloğlu, Bekir, İsbât-ı Vâcib, Ankara, Diyanet Vakfi Yayınları, 1979.

Yurdagür, Metin, “Devir”, DİA, c. 9, 1994. 